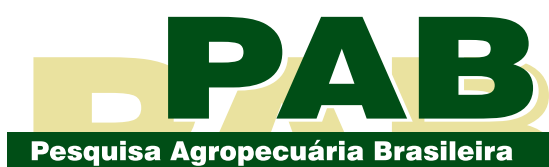

ISSN 1678-3921

Journal homepage: www.embrapa.br/pab

For manuscript submission and journal contents, access: www.scielo.br/pab

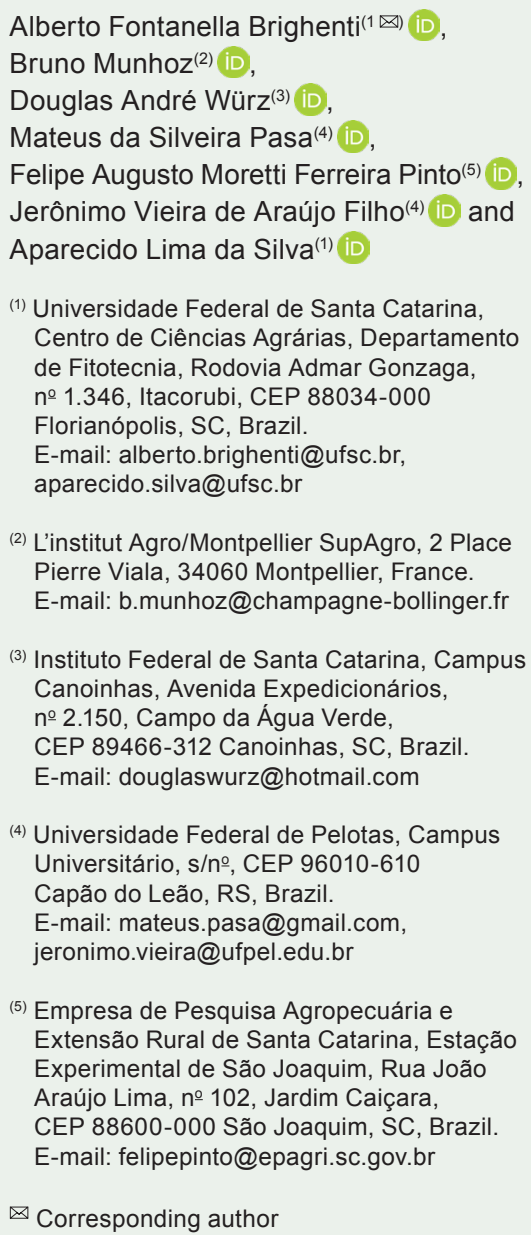

(2) L'institut Agro/Montpellier SupAgro, 2 Place Pierre Viala, 34060 Montpellier, France. E-mail: b.munhoz@champagne-bollinger.fr

(3) Instituto Federal de Santa Catarina, Campus Canoinhas, Avenida Expedicionários, no 2.150, Campo da Água Verde, CEP 89466-312 Canoinhas, SC, Brazil. E-mail: douglaswurz@hotmail.com

(4) Universidade Federal de Pelotas, Campus Universitário, s/no, CEP 96010-610 Capão do Leão, RS, Brazil. E-mail:mateus.pasa@gmail.com, jeronimo.vieira@ufpel.edu.br

(5) Empresa de Pesquisa Agropecuária e Extensão Rural de Santa Catarina, Estação Experimental de São Joaquim, Rua João Araújo Lima, o 102, Jardim Caiçara, CEP 88600-000 São Joaquim, SC, Brazil. E-mail: felipepinto@epagri.sc.gov.br

$\bowtie$ Corresponding author

Received

April 06, 2020

Accepted

August 05, 2020

How to cite BRIGHENTI, A.F.; MUNHOZ, B.; WÜRZ, D.A.; PASA, M. da S.; PINTO, F.A.M.F.; ARAÚJO FILHO, J.V.; SILVA, A.L. da. Techniques to modify cluster architecture and their effect on the viticultural performance of the Sauvignon Blanc cultivar Pesquisa Agropecuária Brasileira, v.55, e01900, 2020. DOI: https://doi.org/10.1590/ S1678-3921.pab2020.v55.01900.

\section{Techniques to modify cluster architecture and their effect on the viticultural performance of the Sauvignon Blanc cultivar}

\begin{abstract}
The objective of this work was to evaluate the effect of different techniques to modify grape cluster architecture on the incidence and severity of botrytis bunch rot, as well as on the viticultural performance of the 'Sauvignon Blanc' grapevine (Vitis vinifera). Associated with fungicides, four treatments were tested: control, $30 \mathrm{ppm}$ gibberellic acid sprayed at full bloom, $1,000 \mathrm{ppm}$ prohexadione calcium sprayed at full bloom, and berry thinning at the stage of beginning of berry touch. The experiment was carried out in the 2015, 2016, and 2017 vintages. Clusters were treated with fungicides during the stages of full bloom, beginning of berry touch, veraison, and around 15 days before harvest. Berry thinning does not cause losses in the yield and quality of 'Sauvignon Blanc', and, despite having little effect on cluster architecture, is effective in reducing the incidence and severity of Botrytis cinerea. Prohexadione calcium improves grape phenolic maturation, is effective in reducing the incidence and severity of $B$. cinerea, and reduces cluster compactness by decreasing berry diameter. The application of gibberellic acid spray at full bloom is not recommended because it decreases yield and bud fertility and increases berry susceptibility to $B$. cinerea infection.
\end{abstract}

Index terms: Botrytis cinerea, Vitis vinifera, berry thinning, gibberellic acid, plant growth regulators, prohexadione calcium.

\section{Técnicas para modificar a arquitetura dos cachos e seu efeito no desempenho vitícola da cultivar Sauvignon Blanc}

Resumo - O objetivo deste trabalho foi avaliar o efeito de diferentes técnicas para modificar a arquitetura de cachos de uva sobre a incidência e a severidade de podridão cinzenta, bem como sobre o desempenho vitícola da videira (Vitis vinifera) 'Sauvignon Blanc'. Associados aos fungicidas, quatro tratamentos foram testados: controle, $30 \mathrm{ppm}$ de ácido giberélico aplicados por pulverização na plena florada, 1.000 ppm de prohexadiona de cálcio aplicados por pulverização na plena florada e raleio de bagas durante a compactação dos cachos. O experimento foi realizado nas safras 2015, 2016 e 2017. Os cachos foram tratados com fungicidas durante os estádios de plena florada, compactação do cacho, veraison e aproximadamente 15 dias antes da colheita. $\mathrm{O}$ raleio de bagas não causa perdas na produtividade e na qualidade de 'Sauvignon Blanc', e, embora tenha pouco efeito na arquitetura do cacho, é eficaz na redução da incidência e da severidade de Botrytis cinerea. A prohexadiona de cálcio melhora a maturação fenólica das uvas, é eficaz na redução da incidência e da severidade de $B$. cinerea e reduz a compactação do cacho ao diminuir o diâmetro das bagas. A aplicação de ácido giberélico 
por pulverização na plena florada não é recomendada por reduzir a produtividade e a fertilidade das gemas e aumentar a suscetibilidade das bagas à infecção por $B$. cinerea .

Termos para indexação: Botrytis cinerea, Vitis vinifera, raleio de bagas, ácido giberélico, reguladores de crescimento vegetal, prohexadiona de cálcio.

\section{Introduction}

In the last decade, the highlands of the state of Santa Catarina, in Southern Brazil, have stood out as a region for the production of high-quality wines (Würz et al., 2018). Of the white varieties, the Sauvignon Blanc grapevine (Vitis vinifera L.) cultivar is the most important and can be considered well adapted to the edaphoclimatic conditions of the region due to its late bud break and to its early/intermediate maturity (Brighenti et al., 2013). These characteristics, associated with specific terroir factors, allow the production of white wines with intense aroma, complexity, and typicity (Würz et al., 2018, 2020a).

However, the climatic conditions in Southern Brazil are also favorable to many fungal pathogens. Botrytis bunch rot or gray mold, caused by the fungi Botryotinia fuckeliana (de Bary) Whetzel and Botrytis cinerea Persoon ex Fries in conidial form, is one of the most important grape diseases in the highland regions of Southern Brazil (Bem et al., 2017). This disease is a problem in regions with cool and wet macroclimates, and, in general, fungal infection is most likely to occur when clusters are dense and little exposed to the sun (Hed et al., 2009; Mundy et al., 2014).

Currently, the strategy for $B$. cinerea control is based mainly on fungicide spraying. However, the sole dependence on this control method is not sustainable due to the emergence of fungicide resistance in $B$. cinerea populations, combined with the adverse effects of pesticides on the environment and human health (Komárek et al., 2010). In addition, fungicide applications post-veraison increase the risk of wine contamination, harming, in some cases, the fermentation process (Leroch et al., 2011). Therefore, pesticide use should be reduced in integrated disease management, showing the need for alternatives to reduce disease epidemics.

The susceptibility to the attack of $B$. cinerea may be related to cluster morphology. As previously mentioned, dense and compact clusters, such as those of 'Sauvignon Blanc', can form a moist microclimate between berries, favoring pathogen development (Hed et al., 2009). Denser clusters may also impair the efficiency of certain fungicides by reducing their penetration/coverage area (Hed et al., 2011). Therefore, a strategy for managing the disease would be to modify cluster architecture.

It is possible to modify cluster architecture in different ways. One of them is by using growth regulators, such as gibberellic acid and prohexadione calcium (Ferree et al., 2003; Molitor et al., 2011; Hanni et al., 2013; Mundy et al., 2014). Another option is berry thinning, which, in Italy, is being widely used either combined with chemical thinning or as an alternative to it (IASMA, 2003; Hanni et al., 2013). This practice is performed in summer, before veraison, especially for the Pinot Blanc, Gewürztraminer, Müller Thurgau, and Sauvignon Blanc cultivars, resulting in reduced cluster compactness and in a lower incidence of diseases (IASMA, 2003).

However, there is little research about the effect of growth regulators or berry thinning on the modification of cluster architecture in the highland regions of Southern Brazil. There are also no known published reports in the country on the impact of combining these techniques with fungicides to control B. cinerea on 'Sauvignon Blanc'.

The objective of this work was to evaluate the effect of different techniques to modify grape cluster architecture on the incidence and severity of botrytis bunch rot, as well as on the viticultural performance of the 'Sauvignon Blanc' grapevine.

\section{Materials and Methods}

The experiment was carried out during the 2014/2015, 2015/2016, and 2016/2017 vintages in a commercial vineyard located in the municipality of São Joaquim, in the state of Santa Catarina, Brazil (28 17'38'S, $49^{\circ} 55^{\prime} 54^{\prime \prime} \mathrm{W}$, at 1,250 $\mathrm{m}$ above sea level). The climate of the region is humid mesothermic, according to Köppen's classification, and the soil is a Cambissolo (Santos et al., 2018), i.e., an Inceptisol, characterized as having high levels of clay (485 $\left.\mathrm{g} \mathrm{kg}^{-1}\right)$ and organic matter $\left(69 \mathrm{~g} \mathrm{~kg}^{-1}\right)$. Meteorological data were obtained from a weather station located approximately $600 \mathrm{~m}$ from the experimental site, including daily rainfall 
(precipitation in $\mathrm{mm}$ ), average temperature $\left({ }^{\circ} \mathrm{C}\right)$, and relative humidity (\%).

The vineyard consisted of approximately 1,000 vines, with ten rows of approximately 100 vines of 13-year-old 'Sauvignon Blanc' grafted onto the 'Paulsen 1103' (Vitis berlandieri Planch. x Vitis rupestris Scheele) rootstock. The vines were trained in a vertical shoot positioning trellis, spaced at $1.5 \times 3.0 \mathrm{~m}$, in the north-south direction; pruned in double spur cordon; and covered with anti-hail nets.

To protect the vineyards against powdery mildew, downy mildew, and anthracnose - caused by the fungi Erysiphe necator Schwein, Plasmopara viticola (Berk. \& M.A. Curtis) Berl. \& De Toni, and Elsinoe ampelina Shear, respectively -, fungicide sprays were applied during the 2014/2015, 2015/2016, and 2016/2017 growing seasons. Each spray contained $200 \mathrm{~g}^{100 \mathrm{~L}^{-1}}$ chlorothalonil, $250 \mathrm{~g} 100 \mathrm{~L}^{-1}$ cymoxanil+mancozeb,

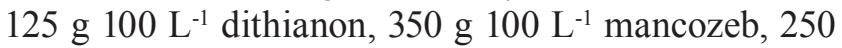

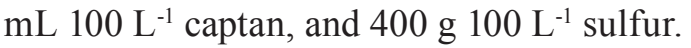

'Sauvignon Blanc' is highly susceptible to Botrytis bunch rot, and the disease was present in the experimental field in previous years. Therefore, all plots were sprayed with $70 \mathrm{~g} 100 \mathrm{~L}^{-1}$ thiophanate-

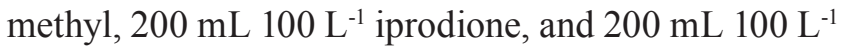
pyrimethanil during the stages of full bloom, beginning of berry touch, veraison, and around 15 days before harvest.

The experimental design was randomized complete blocks, with three blocks, four treatments, and ten plants per plot. The treatments consisted of: $30 \mathrm{ppm}$ gibberellic acid sprayed at full bloom; 1,000 ppm prohexadione calcium (ProCa) sprayed at full bloom; berry thinning at the phenological stage of beginning of berry touch; and control, plots only treated with the fungicides. The phenological stages were determined according to the scale proposed by Lorenz et al. (1995).

Three leaves in the cluster zone of each shoot were removed prior to spraying for a better application of the plant growth regulators. The applied solutions were prepared moments before spraying, with $\mathrm{pH}$ of $\sim 6.95$. The spraying volume was of approximately $1,000 \mathrm{~L} \mathrm{ha}^{-1}$. The grape clusters were sprayed to the point of runoff using the SR 450 motorized hand-gun backpack sprayer (Stihl, São Leopoldo, RS, Brazil), with a flow rate of $2.64 \mathrm{~L} \mathrm{~min}^{-1}$. The vines were sprayed during the morning, with temperature ranging from 20 to $25^{\circ} \mathrm{C}$, relative humidity from 85 to $95 \%$, and wind speed not exceeding $7 \mathrm{~km} \mathrm{~h}^{-1}$. The used source of ProCa was
Viviful (Ihara, Sorocaba, SP, Brazil), with $27.5 \%$ active ingredient. Berry thinning was performed according to Istituto Agrario di San Michele all'Adige (IASMA, 2003), by cutting approximately $1 / 3$ or less of the tip of the cluster.

The concentrations of gibberellic acid and ProCa, as well as spray timing at full bloom, were chosen based on studies conducted in the United States, Luxembourg, and New Zealand, which reported effects of these growth regulators on cluster architecture and Botrytis bunch rot control (Ferree et al., 2003; Molitor et al., 2011; Mundy et al., 2014).

In the middle portion of five vines per plot, ten clusters were randomly selected and marked for assessments of the incidence and severity of Botrytis bunch rot, which began on January 19, 15, and 27 in the 2015, 2016, and 2017 vintages, respectively. Thirty clusters per plot were evaluated at intervals of 7 to 15 days, starting at first symptom appearance, under conditions of natural infection, and continuing until harvest. Incidence was defined as the number of clusters with symptoms divided by the total number of evaluated clusters, whereas severity was determined using the visual diagrammatic scale proposed by Hill et al. (2010), with 12 levels of disease severity.

Botrytis bunch rot disease progress curves were constructed and epidemics were compared in all evaluated growing seasons using the variables area under the disease incidence and severity progress curves (AUDIPC and AUDSPC, respectively). The area under the disease progress curve was calculated as: $\Sigma((\mathrm{Yi}+\mathrm{Yi}+1) / 2)(\mathrm{ti}+1-\mathrm{ti})$, where $\mathrm{Y}$ is the disease intensity (incidence or severity), $t$ is the unit of time, and $i$ is the cumulative number of evaluations (Campbell \& Madden, 1990).

At harvest time, viticultural performance was evaluated by productive and qualitative indexes. The productive variables were: number of clusters per vine, yield per hectare $(\mathrm{Mg})$, fertility index (clusters/shoot), cluster weight $(\mathrm{g})$, berry diameter $(\mathrm{mm})$, and cluster compactness index [(cluster weight)/(cluster length) ${ }^{2}$ ]. The qualitative indexes were: soluble solids ( $\left.{ }^{\circ} \mathrm{Brix}\right)$, titratable acidity $\left(\mathrm{mEq} \mathrm{L}^{-1}\right), \mathrm{pH}$, and total polyphenols (mg L-1 gallic acid) (Singleton \& Rossi, 1965; OIV, 2009).

The obtained data were subjected to the analysis of variance. Shapiro-Wilk's and Bartlett's tests were used to verify the normality and homoscedasticity of the residues. Mean values were compared by Tukey's test, 
at $5 \%$ probability. A standardized principal component analysis (PCA) was used to describe the effect of the treatments on the 12 assessed variables.

\section{Results and Discussion}

The climatic conditions observed in the summer of 2015, 2016, and 2017 were favorable to Botrytis bunch rot occurrence (Figure 1). In January and
February, mean temperatures ranged from 12.8 to $21.4^{\circ} \mathrm{C}$, average relative humidity varied from 53 to $97 \%$, and average total rainfall was $329 \mathrm{~mm}$. The combination of frequent rainfall, mild temperature, and constant humidity, particularly during the harvest period, created wet conditions, which were favorable to infections by $B$. cinerea. Previous studies have shown that, for this fungus, optimal growth occurs at $15-23^{\circ} \mathrm{C}$ and a relative humidity higher than $75 \%$ (Hed
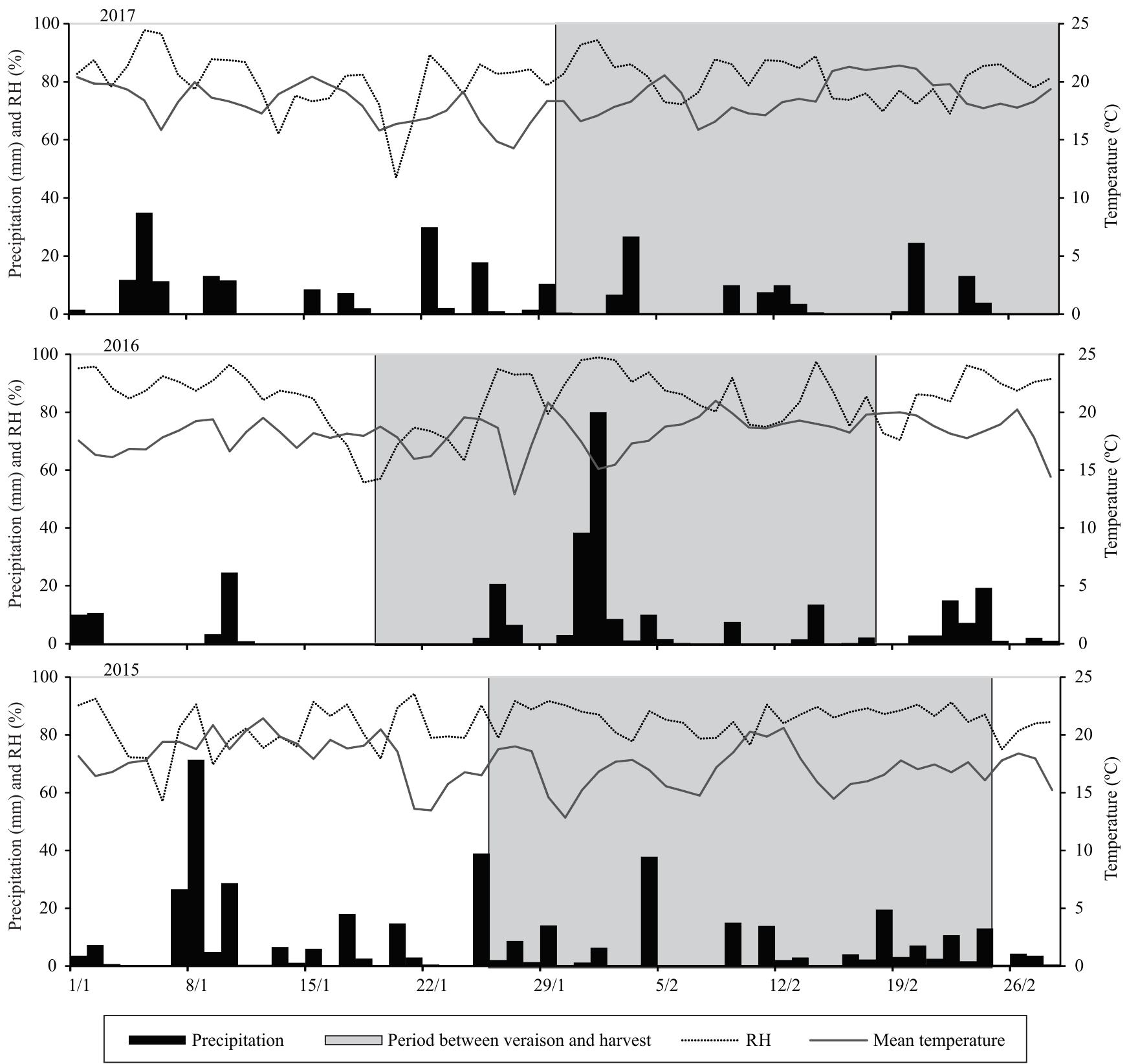

Figure 1. Daily average mean temperature, precipitation, and relative humidity (RH) in January and February, in the first (2015), second (2016), and third (2017) years of evaluation of the 'Sauvignon Blanc' grapevine (Vitis vinifera). 
et al., 2009). Other authors reported similar climatic conditions when studying the Sauvignon Blanc cultivar in the same regions during the 2014, 2015, and 2016 vintages (Bem et al., 2017; Würz et al., 2017, 2020a).

Only applications of synthetic fungicides were not enough to prevent $B$. cinerea infection. Therefore, symptoms of the disease were observed in the control and other treatments (Table 1). Considering the evaluated years, the lowest incidence and severity were verified in 2015, despite the higher accumulated rainfall between January and February.

In the first two years of evaluation, the lowest values in the evolution of AUDIPC and AUDSPC were observed for the berry thinning treatment. In contrast, the highest values were found for the $30 \mathrm{ppm}$ gibberellic acid treatment during the three experimental years (Figure 2). In 2016, a significant increase in the incidence and especially in the severity of $B$. cinerea was recorded for all treatments 15 days after the first evaluation (Figure 2). This can be attributed to the occurrence of heavy rainfall after veraison (Figure 1), which favored disease development.

On average, at harvest, disease incidence was 47.7 and $76.7 \%$ for plants subjected to berry thinning and to $30 \mathrm{ppm}$ gibberellic acid, respectively; these values were the lowest and highest ones, differing statistically (Table 1). The $30 \mathrm{ppm}$ gibberellic acid treatment also showed the highest average severity of 32.1\% at harvest and the highest AUDIPC and AUDSPC values, with respective averages of 1,269.1 and 357.7. For the control, 1,000 ppm ProCa, and berry thinning, no significant differences were observed between AUDIPC and AUDSPC.

The results obtained in the present work differ from those of other authors, who studied the effect of gibberellic acid on the reduction of Botrytis bunch rot. In Southern Brazil, Silva et al. (2019) concluded that spraying 2 to $8 \mathrm{ppm}$ gibberellic acid at pre-flowering was efficient in controlling B. cinerea on 'Sauvignon Blanc'. Hed et al. (2011), however, reported that the control of the fungus Botrytis sp. on the Vignoles hybrid was only possible with $10 \mathrm{ppm}$ gibberellic acid before bloom and two sprays of fungicide. Likewise, Reynolds et al. (2006) found a positive effect of gibberellic acid sprays, including the reduction of cluster compactness and improvement of the favorable microclimate within clusters, reducing Botrytis infection and bunch rot.

The positive effect of ProCa combined with fungicides on the control of $B$. cinerea, as observed in the present study, was confirmed by other authors in different locations and with different cultivars. Molitor et al. (2011) reported that leaf removal, together with ProCa sprays, was highly efficient in the control of B. cinerea on 'Pinot Gris' and 'Pinot Blanc', which was attributed to better sun and wind exposure due to a reduced cluster density. Similar results were also found for the 'Riesling' grapevine by Baus et al. (2011), who pointed out that sprays of ProCa at full bloom, combined with leaf removal and fungicides, were effective for Botrytis bunch rot control.

ProCa is expected to be metabolized in grapes between two to three weeks after its application, without leaving any residues neither in the vineyard

Table 1. Incidence, severity, and area under the incidence (AUDIPC) and severity (AUDSPC) progress curves of Botrytis bunch rot on the 'Sauvignon Blanc' grapevine (Vitis vinifera) subjected to different treatments to modify cluster architecture in 2015, 2016, and 2017 vintages $^{(1)}$.

\begin{tabular}{|c|c|c|c|c|c|c|c|c|}
\hline Treatment $^{(2)}$ & 2015 & 2016 & 2017 & Average & 2015 & 2016 & 2017 & Average \\
\hline & \multicolumn{4}{|c|}{ Incidence of Botrytis cinerea $(\%)$} & \multicolumn{4}{|c|}{ Severity of Botrytis cinerea $(\%)$} \\
\hline Control & $43.1 \mathrm{a}$ & $82.9 \mathrm{a}$ & $62.8 \mathrm{ab}$ & $56.6 \mathrm{ab}$ & $6.7 \mathrm{ab}$ & $34.5 \mathrm{ab}$ & $9.6 \mathrm{~b}$ & $18.2 \mathrm{ab}$ \\
\hline $\mathrm{GA}_{3}$ & $57.6 \mathrm{a}$ & $87.7 \mathrm{a}$ & $91.3 \mathrm{a}$ & $76.7 \mathrm{a}$ & $10.0 \mathrm{a}$ & $43.7 \mathrm{a}$ & $34.5 \mathrm{a}$ & $32.1 \mathrm{a}$ \\
\hline ProCa & $45.8 \mathrm{a}$ & $61.2 \mathrm{~b}$ & $50.6 \mathrm{~b}$ & $57.7 \mathrm{ab}$ & $6.5 \mathrm{ab}$ & $30.0 \mathrm{ab}$ & $12.3 \mathrm{~b}$ & $17.0 \mathrm{~b}$ \\
\hline \multirow[t]{2}{*}{ Berry thinning } & $26.6 b$ & $50.4 \mathrm{~b}$ & $57.9 \mathrm{ab}$ & $47.7 \mathrm{~b}$ & $1.8 \mathrm{~b}$ & $18.4 \mathrm{~b}$ & $10.8 \mathrm{~b}$ & $10.7 \mathrm{~b}$ \\
\hline & \multicolumn{4}{|c|}{ AUDIPC } & \multicolumn{4}{|c|}{ AUDSPC } \\
\hline Control & $648.0 \mathrm{ab}$ & $994.6 \mathrm{ab}$ & $750.5 b$ & $777.1 \mathrm{~b}$ & $128.2 \mathrm{ab}$ & $300.0 \mathrm{ab}$ & $122.3 b$ & $162.1 \mathrm{~b}$ \\
\hline $\mathrm{GA}_{3}$ & $1222.8 \mathrm{a}$ & $1202.5 \mathrm{a}$ & $1487.3 \mathrm{a}$ & $1269.1 \mathrm{a}$ & $247.0 \mathrm{a}$ & $384.4 \mathrm{a}$ & $522.6 \mathrm{a}$ & $357.7 \mathrm{a}$ \\
\hline ProCa & $721.5 \mathrm{ab}$ & $839.6 \mathrm{ab}$ & $1073.7 \mathrm{ab}$ & $865.4 b$ & $111.7 \mathrm{~b}$ & $320.9 \mathrm{a}$ & $153.5 \mathrm{~b}$ & $176.7 \mathrm{~b}$ \\
\hline Berry thinning & $372.2 \mathrm{~b}$ & $709.8 \mathrm{~b}$ & $921.0 \mathrm{~b}$ & $657.6 \mathrm{~b}$ & $29.0 \mathrm{~b}$ & $191.9 \mathrm{~b}$ & $130.5 \mathrm{~b}$ & $106.7 \mathrm{~b}$ \\
\hline
\end{tabular}

${ }^{(1)}$ Means followed by different letters, in the columns, differ by Tukey's test, at $5 \%$ probability. ${ }^{(2)} \mathrm{GA}_{3}$, gibberellic acid at 30 ppm; and ProCa, prohexadione calcium at $1,000 \mathrm{ppm}$. 
nor on the wine. Therefore, the combination of ProCa and leaf removal could represent a strategy for sustainable viticulture to reduce pesticide input into the environment (Molitor et al., 2011).

Berry thinning was also effective in reducing the incidence and severity of $B$. cinerea, as also concluded by other authors (IASMA, 2003; Hanni et al., 2013). However, it is important to note that berry thinning is extremely labor intensive, and can, therefore, be considered an option only for small vineyards and small farms (Hanni et al., 2013).
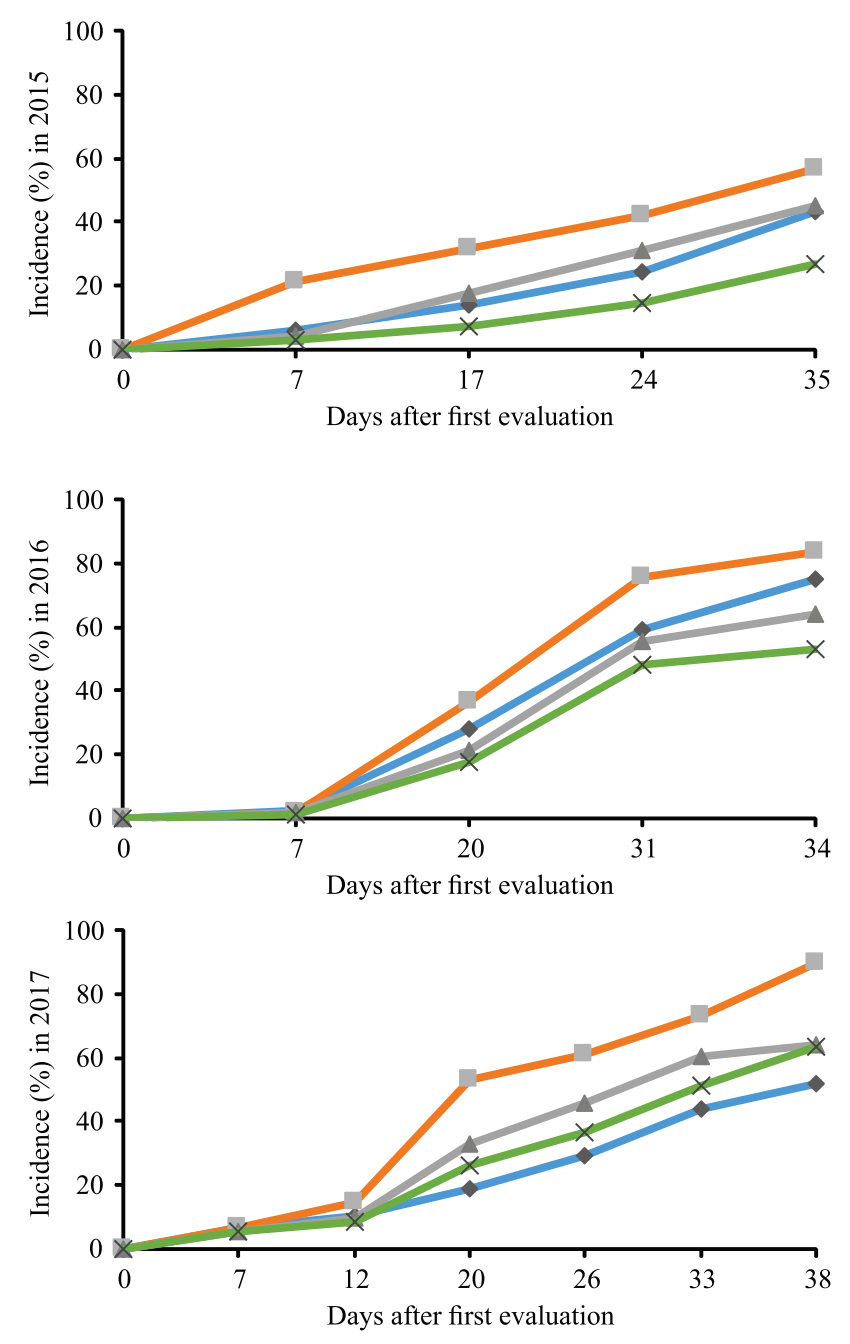

In 2015, there were no differences between treatments for number of clusters per vine and fertility index (number of clusters per shoot). However, in 2016, 2017, and for the average of the three evaluated vintages, the plants treated with gibberellic acid produced less clusters and showed a lower fertility index, compared with the other treatments (Table 2). This result is a consequence of the reduction in meristem differentiation in fertile buds due to the application of gibberellic acid in the year preceding the evaluated growth cycle. The obtained results are indicative that gibberellic acid sprays at concentrations
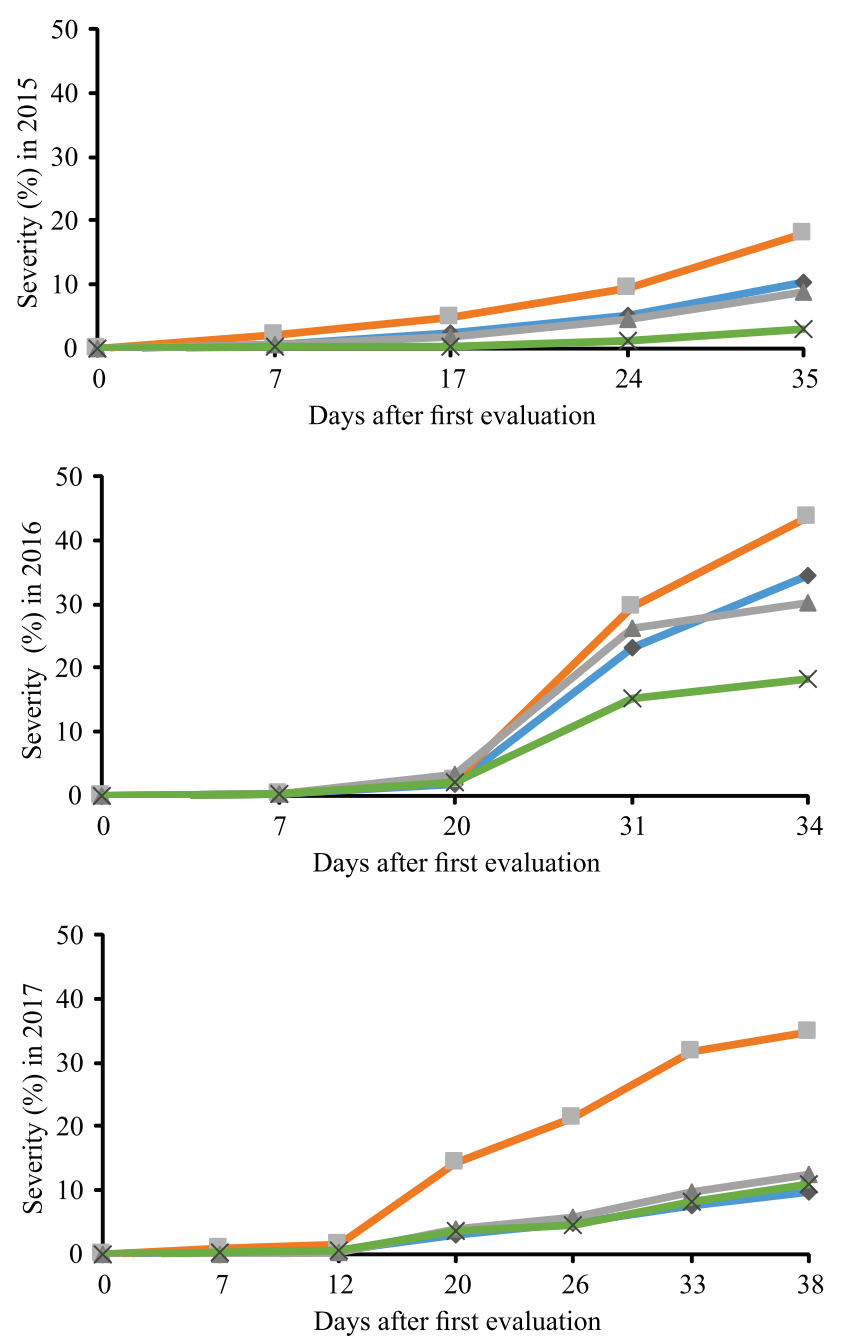
Control 30 ppm GA $3-1000$ ppm ProCa $\leftarrow$ Berry thinning

Figure 2. Incidence and severity progress curves of Botrytis bunch rot on the 'Sauvignon Blanc' grapevine (Vitis vinifera) subjected to different treatments to modify cluster architecture in 2015, 2016, and 2017 vintages. $\mathrm{GA}_{3}$, gibberellic acid; and ProCa, prohexadione calcium. 
below $10 \mathrm{ppm}$ may be insufficient to significantly modify the cluster architecture of 'Sauvignon Blanc'; however, concentrations above this value may decrease the number of fertile buds and clusters for the next season (Bugaret et al., 2006; Mundy et al., 2014).

For yield and cluster weight, no differences were found between the control and berry thinning. Both showed superior results to gibberellic acid and ProCa (Table 2). When the control was compared with gibberellic acid, there was a 55\% reduction in yield per hectare and a $34 \%$ reduction in cluster weight. When the control was compared with ProCa, there was a $41 \%$ reduction in yield per hectare and a $37 \%$ reduction in cluster weight. However, Hanni et al. (2013) observed a $19 \%$ reduction in cluster weight in plants subjected to berry thinning, which was not confirmed in the present study. It is important to highlight that, even though approximately $1 / 3$ of the cluster was removed, berry thinning did not cause losses in plant yield and was also efficient in reducing the incidence and severity of Botrytis bunch rot. Similar results were obtained in northern Italy, specifically for 'Sauvignon Blanc' (IASMA, 2003).
The change in cluster architecture caused by gibberellic acid sprays at full bloom is usually related to the decrease in the number of berries per cluster, as well as to rachis lengthening (Hed et al., 2011), which explained the reduced yield and cluster weight in the present work.

For ProCa, other authors also observed a reduction in plant yield when this growth regulator was applied at full bloom (Lo Giudice et al., 2004; Molitor et al., 2011; Mundy et al., 2014; Würz et al., 2020b).

The effect of the treatments on berry diameter varied according to the vintage. On average, the largest berry diameter was observed for the control and clusters treated with gibberellic acid (Table 2). The application of ProCa reduced berry diameter, as also reported by other authors (Lo Giudice et al., 2004; Würz et al., 2020b). This reduction in berry diameter and weight can be explained by a reduced gibberellic acid biosynthesis, especially when ProCa is applied close to full bloom (Lo Giudice et al., 2004).

In all vintages, the plants treated with gibberellic acid and ProCa produced less compact clusters (Table 2). The spray of gibberellic acid caused the

Table 2. Productive indexes for the 'Sauvignon Blanc' grapevine (Vitis vinifera) subjected to different treatments to modify cluster architecture in 2015, 2016, and 2017 vintages $^{(1)}$.

\begin{tabular}{|c|c|c|c|c|c|c|c|c|}
\hline Treatment ${ }^{(2)}$ & 2015 & 2016 & 2017 & Average & 2015 & 2016 & 2017 & Average \\
\hline & \multicolumn{4}{|c|}{ Clusters per vine } & \multicolumn{4}{|c|}{ Yield $\left(\mathrm{Mg} \mathrm{ha}^{-1}\right)$} \\
\hline Control & $47.0 \mathrm{a}$ & $37.8 \mathrm{a}$ & $39.5 \mathrm{a}$ & $40.2 \mathrm{a}$ & $14.9 \mathrm{a}$ & $7.9 \mathrm{ab}$ & $8.9 \mathrm{a}$ & $10.3 \mathrm{a}$ \\
\hline $\mathrm{GA}_{3}$ & $42.1 \mathrm{a}$ & $14.3 b$ & $26.4 \mathrm{~b}$ & $28.2 b$ & $6.9 \mathrm{~b}$ & $1.9 \mathrm{c}$ & $4.9 \mathrm{~b}$ & $4.6 \mathrm{~b}$ \\
\hline ProCa & $45.8 \mathrm{a}$ & $37.7 \mathrm{a}$ & $35.6 \mathrm{ab}$ & $38.1 \mathrm{a}$ & $8.2 b$ & $6.2 b$ & $4.6 b$ & $6.1 b$ \\
\hline \multirow[t]{2}{*}{ Berry thinning } & $53.4 \mathrm{a}$ & $41.4 \mathrm{a}$ & $36.9 \mathrm{ab}$ & $42.8 \mathrm{a}$ & $16.8 \mathrm{a}$ & $8.6 \mathrm{a}$ & $8.5 \mathrm{a}$ & $11.2 \mathrm{a}$ \\
\hline & \multicolumn{4}{|c|}{ Cluster weight (g) } & \multicolumn{4}{|c|}{ Fertility index (clusters per shoot) } \\
\hline Control & $141.5 \mathrm{a}$ & $94.9 \mathrm{a}$ & $102.2 \mathrm{a}$ & $111.6 \mathrm{a}$ & $1.6 \mathrm{a}$ & $1.5 \mathrm{a}$ & $1.2 \mathrm{a}$ & $1.4 \mathrm{a}$ \\
\hline $\mathrm{GA}_{3}$ & $77.2 \mathrm{~b}$ & $58.6 b$ & $86.3 \mathrm{~b}$ & $73.5 b$ & $1.6 \mathrm{a}$ & $0.6 \mathrm{~b}$ & $0.8 b$ & $1.0 \mathrm{~b}$ \\
\hline ProCa & $82.7 \mathrm{~b}$ & $74.7 \mathrm{ab}$ & $54.5 \mathrm{c}$ & $70.8 b$ & $1.5 \mathrm{a}$ & $1.5 \mathrm{a}$ & $1.2 \mathrm{a}$ & $1.3 \mathrm{a}$ \\
\hline \multirow[t]{2}{*}{ Berry thinning } & $139.9 \mathrm{a}$ & $100.7 \mathrm{a}$ & $105.1 \mathrm{a}$ & $115.9 \mathrm{a}$ & $1.5 \mathrm{a}$ & $1.5 \mathrm{a}$ & $1.1 \mathrm{a}$ & $1.4 \mathrm{a}$ \\
\hline & \multicolumn{4}{|c|}{ Berry diameter (mm) } & \multicolumn{4}{|c|}{ Compactness index } \\
\hline Control & $14.9 \mathrm{a}$ & $15.4 \mathrm{a}$ & $14.1 \mathrm{a}$ & $14.8 \mathrm{a}$ & $0.98 \mathrm{ab}$ & $0.96 \mathrm{a}$ & $0.75 \mathrm{a}$ & $0.90 \mathrm{a}$ \\
\hline $\mathrm{GA}_{3}$ & $14.7 \mathrm{a}$ & $14.8 \mathrm{ab}$ & $14.2 \mathrm{a}$ & $14.6 \mathrm{a}$ & $0.54 \mathrm{c}$ & $0.72 b$ & $0.57 \mathrm{~b}$ & $0.61 b$ \\
\hline ProCa & $14.5 \mathrm{a}$ & $14.9 \mathrm{ab}$ & $11.7 \mathrm{~b}$ & $13.7 b$ & $0.87 \mathrm{~b}$ & $0.78 b$ & $0.45 \mathrm{c}$ & $0.70 \mathrm{~b}$ \\
\hline Berry thinning & $12.5 \mathrm{~b}$ & $14.6 \mathrm{~b}$ & $14.1 \mathrm{a}$ & $13.7 \mathrm{~b}$ & $1.11 \mathrm{a}$ & $0.94 \mathrm{a}$ & $0.82 \mathrm{a}$ & $0.95 \mathrm{a}$ \\
\hline
\end{tabular}


highest reduction in cluster compactness and was effective for chemical thinning, as also found by Bugaret et al. (2006) and Mundy et al. (2014). The main effect of ProCa on cluster morphology was the decrease in berry diameter, which resulted in reduced compactness, cluster weight, and yield. This active ingredient can abort flower development when applied, at very high concentrations, at flowering and can also cause cluster drop in the peduncle zone (Avizcuri-Inac et al., 2013).

Although the clusters treated with gibberellic acid showed lower compactness, they presented the highest incidence and severity of Botrytis bunch rot. Therefore, the gibberellic acid sprays may have increased berry susceptibility to fungal attack.

On the average of three experimental years, there were no significant differences regarding soluble solids and $\mathrm{pH}$ between the four treatments (Table 3). Furthermore, the results obtained for titratable acidity were not conclusive, confirming the difficulty in establishing direct relationships between grape maturation and the use of gibberellic acid or ProCa on the clusters of $V$. vinifera. Mundy et al. (2014) and Avizcuri-Inac et al. (2013) pointed out that those variables usually differ according to the weather conditions of each growing season.

Clusters treated with ProCa produced berries with greater total polyphenol contents (Table 3). This suggests that further studies should be conducted to evaluate the specific effect of ProCa sprays on grape phenolic composition, especially since the increase in total polyphenol content may be related to a higher resistance to Botrytis bunch rot. According to Bazzi et al. (2003), the frequent application of ProCa can induce pathogen resistance by the biosynthesis of 3-deoxyflavonoids that act similarly to phytoalexins, which are responsible for the defense mechanism of plants against pathogens and infections.

The PCA was used to characterize and describe the effects of the treatments on the 12 analyzed variables. Separately, factor 1 (PC1) and factor 2 (PC2) explain, respectively, 41.5 and $23.0 \%$ of data variation (Figure 3); together, they explain $64.5 \%$ of total variability. The dispersion of the treatments can be observed from their distribution in the coordinate system.

According to the PCA, the control and berry thinning treatments showed similar results, higher yields, heavy and compact clusters, and a low incidence and severity of Botrytis bunch rot. At the other extreme, $30 \mathrm{ppm}$ gibberellic acid had the lowest bud fertility, lowest yield, light and less compact clusters, and a high incidence and severity of Botrytis bunch rot. The 1,000 ppm ProCa treatment at full bloom presented loose clusters with small berries, the highest mean value of total polyphenols, and a low incidence and severity of Botrytis bunch rot when compared with the control.

Table 3. Qualitative indexes for the 'Sauvignon Blanc' grapevine (Vitis vinifera) subjected to different treatments to modify cluster architecture in 2015, 2016, and 2017 vintages $^{(1)}$.

\begin{tabular}{|c|c|c|c|c|c|c|c|c|}
\hline Treatment $^{(2)}$ & 2015 & 2016 & 2017 & Average & 2015 & 2016 & 2017 & Average \\
\hline & \multicolumn{4}{|c|}{ Soluble solids ( $\left.{ }^{\circ} \mathrm{Brix}\right)$} & \multicolumn{4}{|c|}{ Total acidity $\left(\mathrm{mEq} \mathrm{L}^{-1}\right)$} \\
\hline Control & $19.9 \mathrm{a}$ & $19.4 \mathrm{a}$ & $20.6 \mathrm{a}$ & $19.9 \mathrm{a}$ & $104.5 \mathrm{a}$ & $96.0 \mathrm{c}$ & $125.0 \mathrm{ab}$ & $108.5 b$ \\
\hline $\mathrm{GA}_{3}$ & $19.6 \mathrm{a}$ & $18.3 b$ & $20.6 \mathrm{a}$ & $19.5 \mathrm{a}$ & $108.0 \mathrm{a}$ & $148.1 b$ & $138.7 \mathrm{a}$ & $131.6 \mathrm{ab}$ \\
\hline ProCa & $20.2 \mathrm{a}$ & $18.8 \mathrm{ab}$ & $21.2 \mathrm{a}$ & $20.1 \mathrm{a}$ & $103.3 \mathrm{a}$ & $113.0 \mathrm{c}$ & $123.7 \mathrm{ab}$ & $113.6 \mathrm{ab}$ \\
\hline \multirow[t]{2}{*}{ Berry thinning } & $19.6 \mathrm{a}$ & $19.4 \mathrm{a}$ & $21.5 \mathrm{a}$ & $20.2 \mathrm{a}$ & $114.9 \mathrm{a}$ & $170.0 \mathrm{a}$ & $114.0 \mathrm{~b}$ & $133.0 \mathrm{a}$ \\
\hline & \multicolumn{4}{|c|}{$\mathrm{pH}$} & \multicolumn{4}{|c|}{ Total polyphenols (mg L ${ }^{-1}$ gallic acid) } \\
\hline Control & $3.00 \mathrm{a}$ & $3.00 \mathrm{a}$ & $2.96 \mathrm{a}$ & $3.02 \mathrm{a}$ & $520.3 b$ & $444.9 b$ & $533.7 b$ & $499.6 b$ \\
\hline $\mathrm{GA}_{3}$ & $3.15 \mathrm{a}$ & $3.10 \mathrm{a}$ & $2.96 \mathrm{a}$ & $3.07 \mathrm{a}$ & $439.0 \mathrm{c}$ & $492.4 \mathrm{a}$ & $515.2 b$ & $482.2 b$ \\
\hline ProCa & $3.21 \mathrm{a}$ & $3.04 \mathrm{a}$ & $2.90 \mathrm{a}$ & $3.05 \mathrm{a}$ & $579.3 \mathrm{a}$ & $478.5 \mathrm{a}$ & $573.3 \mathrm{a}$ & $543.7 \mathrm{a}$ \\
\hline Berry thinning & $3.10 \mathrm{a}$ & $3.12 \mathrm{a}$ & $2.99 \mathrm{a}$ & $3.07 \mathrm{a}$ & $442.3 \mathrm{c}$ & $408.3 c$ & $479.3 c$ & $443.3 b$ \\
\hline
\end{tabular}

${ }^{(1)}$ Means followed by different letters, in the columns, differ by Tukey’s test, at $5 \%$ probability. ${ }^{(2)} \mathrm{GA}_{3}$, gibberellic acid at 30 ppm; and ProCa, prohexadione calcium at 1,000 ppm. 


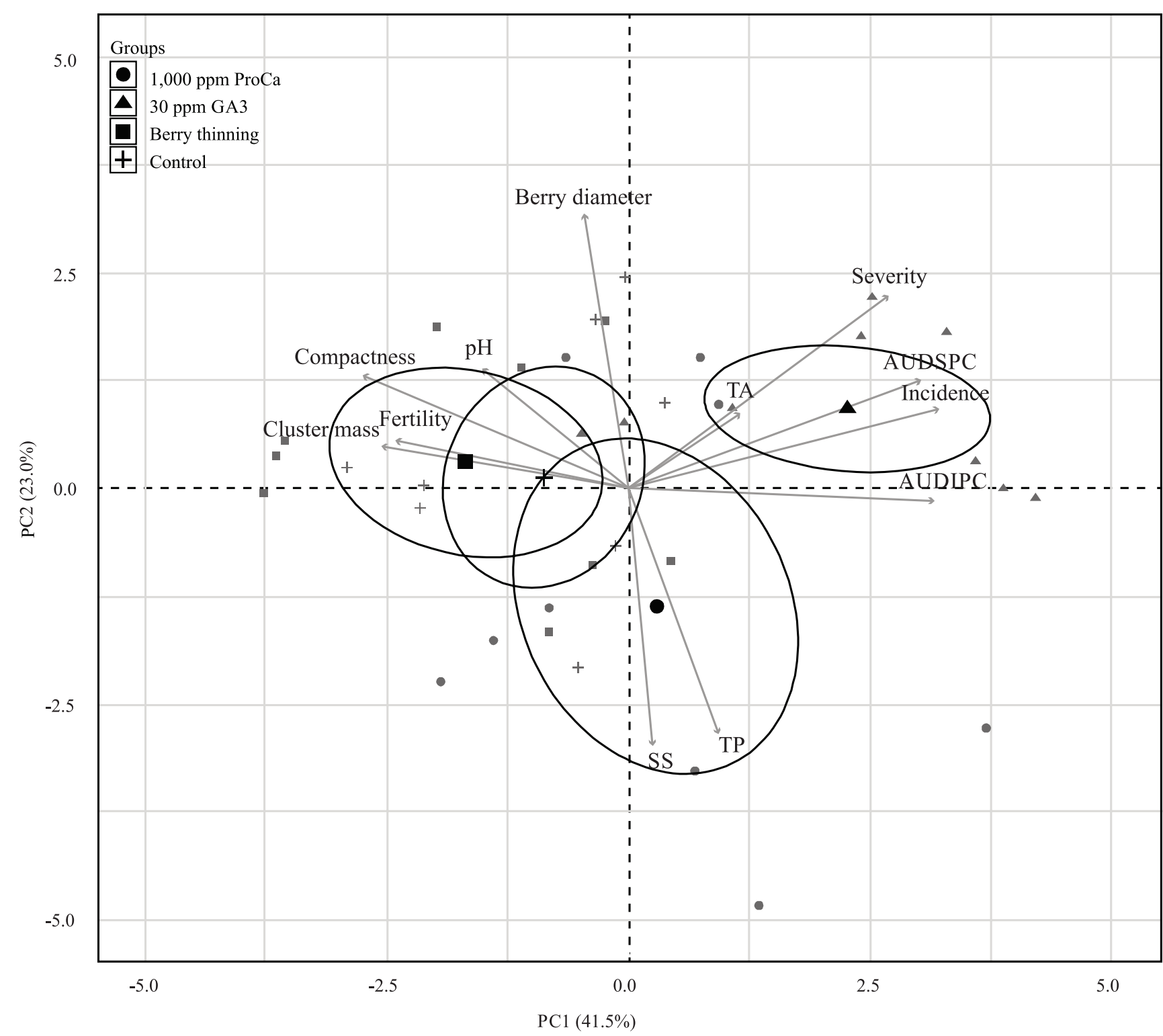

Figure 3. Projection of the principal component (PC) analysis of the 12 variables used to evaluate the performance of the 'Sauvignon Blanc' grapevine (Vitis vinifera) subjected to the following treatments, in 2015, 2016, and 2017 vintages: control, $30 \mathrm{ppm}$ gibberellic acid $\left(\mathrm{GA}_{3}\right), 1,000 \mathrm{ppm}$ prohexadione calcium (ProCa), and berry thinning. TA, titratable acidity; TP, total polyphenols; and SS, soluble solids.

\section{Conclusions}

1. Berry thinning does not cause losses in the yield and quality of the 'Sauvignon Blanc' grapevine (Vitis vinifera), and, despite having little effect on cluster architecture, is effective in reducing the incidence and severity of the fungus Botrytis cinerea.
2. Prohexadione calcium improves phenolic maturation, is effective in reducing the incidence and severity of $B$. cinerea, and reduces cluster compactness by decreasing berry diameter.

3. Gibberellic acid sprays at full bloom are not recommended because they cause decreases in yield and increases in berry susceptibility to $B$. cinerea infection. 


\section{References}

AVIZCURI-INAC, J.-M.; GONZALO-DIAGO, A.; SANZASENSIO, J.; MARTÍNEZ-SORIA, M.-T.; LÓPEZ-ALONSO, M.; DIZY-SOTO, M.; ECHÁVARRI-GRANADO, J.-F.; VAQUERO-FERNÁNDEZ, L.; FERNÁNDEZ-ZURBANO, P. Effect of cluster thinning and prohexadione calcium applications on phenolic composition and sensory properties of red wines. Journal of Agricultural and Food Chemistry, v.61, p.1124-1137, 2013. DOI: https://doi.org/10.1021/jf304257r.

BAUS, O.; REINEKE, A.; BERKELMANN-LÖHNERTZ, B. Control of grey mould by application of gibberellin acid inhibitor $\left(\right.$ Regalis $^{\circledR}$ ) and management practices in Vitis vinifera (cv. Riesling). IOBC-WPRS Bulletin, v.67, p.49-53, 2011.

BAZZI, C.; MESSINA, C.; TORTORETO, L.; STEFANI, E.; BIN, F.; BRUNELLI, A.; ANDREOTTI, C.; SABATINI, E.; SPINELLI, F.; COSTA, G.; HAUPTMANN, S.; STAMMLER, G.; DOERR, S.; MARR, J.; RADEMACHER, W. Control of pathogen incidence in pome fruits and other horticultural crop plants with prohexadione-Ca. European Journal of Horticultural Science, v.68, p.108-114, 2003.

BEM, B.P. de; BOGO, A.; ALLEBRANDT, R.; MARCON FILHO, J.L.; WÜRZ, D.A.; BRIGHENTI, A.F.; RUFATO, L. Botrytis bunch rot on 'Sauvignon Blanc' grapevine on the Y-trellis and vertical shoot-positioned training systems. Pesquisa Agropecuária Brasileira, v.52, p.818-822, 2017. DOI: https://doi.org/10.1590/s0100-204x2017000900015.

BRIGHENTI, A.F.; BRIGHENTI, E.; BONIN, V.; RUFATO, L. Caracterização fenológica e exigência térmica de diferentes variedades de uvas viníferas em São Joaquim, Santa Catarina - Brasil. Ciência Rural, v.43, p.1162-1167, 2013. DOI: https://doi.org/10.1590/S0103-84782013005000082.

BUGARET, Y.; RIEUBLANC, S.; BUROSSE, L.; MOREIRA, V.; QUEYRENS, J. Diminuer la compacité des grappes pour prevenir leurs maladies: effets d'un stimulateur de croissance à base de gibberelline. Phytoma, v.593, p.45-49, 2006.

CAMPBELL, C.L.; MADDEN, L.V. Introduction to plant disease epidemiology. New York: Wiley, 1990.

FERREE, D.C.; ELLIS, M.A.; MCARTNEY, S.J.; BROWN, M.V.; SCURLOCK, D.M. Comparison of fungicide, leaf removal and gibberellic acid on development of grape clusters and Botrytis bunch rot of 'Vignoles' and 'Pinot Gris'. Small Fruits Review, v.2, p.3-18, 2003. DOI: https://doi.org/10.1300/J301v02n04_02.

HANNI, E.; LARDSCHNEIDER, E.; KELDERER, M. Alternatives to the use of gibberellins for bunch thinning and bunch compactness reduction on grapevine. Acta Horticulturae, v.978, p.335-345, 2013. DOI: https://doi.org/10.17660/ ActaHortic.2013.978.39.

HED, B.; NGUGI, H.K.; TRAVIS, J.W. Relationship between cluster compactness and bunch rot in Vignoles grapes. Plant Disease, v.93, p.1195-1201, 2009. DOI: https://doi.org/10.1094/ PDIS-93-11-1195.

HED, B.; NGUGI, H.K.; TRAVIS, J.W. Use of gibberellic acid for management of bunch rot on Chardonnay and Vignoles grape.
Plant Disease, v.95, p.269-278, 2011. DOI: https://doi.org/10.1094/ PDIS-05-10-0382.

HILL, G.N.; BERESFORD, R.M.; EVANS, K.J. Tools for accurate assessment of botrytis bunch rot (Botrytis cinerea) on wine grapes. New Zealand Plant Protection, v.63, p.174-181, 2010. DOI: https://doi.org/10.30843/nzpp.2010.63.6560.

IASMA. Istituto Agrario di San Michele all'Adige. Proposte di diradamento chimico in viticoltura. IASMA Notizie, v.6, p.1-2, 2003.

KOMÁREK, M.; ČADKOVÁ, E.; CHRASTNÝ, V.; BORDAS, F.; BOLLINGER, J.-C. Contamination of vineyard soils with fungicides: a review of environmental and toxicological aspects. Environment International, v.36, p.138-151, 2010. DOI: https://doi.org/10.1016/j.envint.2009.10.005.

LEROCH, M.; KRETSCHMER, M.; HAHN, M. Fungicide resistance phenotypes of Botrytis cinerea isolates from commercial vineyards in south west Germany. Journal of Phytopathology, v.159, p.63-65, 2011. DOI: https://doi.org/10.1111/j.1439-0434.2010.01719.x.

LO GIUDICE, D.; WOLF, T.K.; ZOECKLEIN, B.W. Effects of prohexadione-calcium on grape yield components and fruit and wine composition. American Journal of Enology and Viticulture, v.55, p.73-83, 2004.

LORENZ, D.H.; EICHHORN, K.W.; BLEIHOLDER, H.; KLOSE, R.; MEIER, U.; WEBER, E. Growth stages of the grapevine: phenological growth stages of the grapevine (Vitis vinifera L. ssp. vinifera) - codes and descriptions according to the extended BBCH scale. Australian Journal of Grape and Wine Research, v.1, p.100-103, 1995. DOI: https://doi.org/10.1111/j.1755-0238.1995. tb00085.x.

MOLITOR, D.; ROTHMEIER, M.; BEHR, M.; FISCHER, S.; HOFFMANN, L.; EVERS, D. Crop cultural and chemical methods to control grey mould on grapes. Vitis, v.50, p.81-87, 2011. DOI: https://doi.org/10.5073/vitis.2011.50.81-87.

MUNDY, D.C.; HAYCOCK, S.R.; RAW, V.; AGNEW, R.H.; SHERMAN, E.; MCLACHLAN, A.R.G.; HAGERTY, G.C. Effects of chemical and natural product treatments on bunch openness and botrytis bunch rot in Sauvignon blanc grapes. New Zealand Plant Protection, v.67, p.157-167, 2014. DOI: https://doi.org/10.30843/nzpp.2014.67.5747.

OIV. Organisation Internationale de la Vigne et du Vin. Recueil des methodes internationales d'analyse des vins et des moûts. Paris, 2009. 368p.

REYNOLDS, A.G.; ROLLER, J.N.; FORGIONE, A.; DE SAVIGNY, C. Gibberellic acid and basal leaf removal: implications for fruit maturity, vestigial seed development, and sensory attributes of Sovereign Coronation table grapes. American Journal of Enology and Viticulture, v.57, p.41-53, 2006.

SANTOS, H.G. dos; JACOMINE, P.K.T.; ANJOS, L.H.C. dos; OLIVEIRA, V.A. de; LUMBRERAS, J.F.; COELHO, M.R.; ALMEIDA, J.A. de; ARAUJO FILHO, J.C. de; OLIVEIRA, J.B. de; CUNHA, T.J.F. Sistema brasileiro de classificação de solos. 5.ed. rev. e ampl. Brasília: Embrapa, 2018. E-book.

Pesq. agropec. bras., Brasília, v.55, e01900, 2020

DOI: 10.1590/S1678-3921.pab2020.v55.01900 
SILVA, P.S. da; KIRINUS, M.B.M.; BARRETO, C.F.; LAMELA, C.S.P.; MALGARIM, M.B.; MELLO-FARIAS, P. Gibberellic acid reduces clusters rot of 'Sauvignon blanc' grapes. Revista Brasileira de Fruticultura, v.41, e-486, 2019. DOI: https://doi.org/10.1590/0100-29452019486.

SINGLETON, V.L.; ROSSI, J.A. Colorimetry of total phenolics with phosphomolybdic-phosphotungstic acid reagents. American Journal of Enology and Viticulture, v.16, p.144-158, 1965.

WÜRZ, D.A.; ALLEBRANDT, R.; MARCON FILHO, J.L.; BEM, B.P. de; BRIGHENTI, A.F.; RUFATO, L.; KRETZSCHMAR, A.A. Época de desfolha e sua influência no desempenho vitícola da uva 'Sauvignon Blanc' em região de elevada altitude. Revista de Ciências Agroveterinárias, v.17, p.91-99, 2018. DOI: https://doi.org/10.5965/223811711712018091.

WÜRZ, D.A.; BRIGHENTI, A.F.; ALLEBRANDT, R.; MARCON FILHO, J.L.; BEM, B.P. de; ARAÚJO FILHO, J.V.; RUFATO, L.; KRETZSCHMAR, A.A. Desfolha precoce como estratégia de controle da podridão de Botrytis cinerea na videira Cabernet Sauvignon em regiões de altitude. Summa Phytopathologica, v.43, p.111-117, 2017. DOI: https://doi.org/10.1590/0100-5405/169870.

WÜRZ, D.A.; MARCON FILHO, J.L.; ALLEBRANDT, R.; BRIGHENTI, A.F.; BEM, B.P. de; RUFATO, L.; KRETZSCHMAR, A.A. Desempenho agronômico da videira 'Cabernet Sauvignon' submetida a diferentes épocas de aplicação e concentrações de Prohexadiona de Cálcio. Revista de Ciências Agroveterinárias, v.19, p.8-15, 2020b. DOI: https://doi.org/10.5965/223811711912020008.

WÜRZ, D.A.; RUFATO, L.; BOGO, A.; ALLEBRANDT, R.; BEM, B.P. de; MARCON FILHO, J.L.; BRIGHENTI, A.F.; BONIN, B.F. Effects of leaf removal on grape cluster architecture and control of Botrytis bunch rot in Sauvignon Blanc grapevines in Southern Brazil. Crop Protection, v.131, art.105079, 2020a. DOI: https://doi.org/10.1016/j.cropro.2020.105079. 